\title{
THE SALE OF THE FLESH OF TUBERCULOUS CATTLE FOR HUMAN FOOD.*
}

\author{
BY HENRY E. AIMSTRONG, D.Hr., \\ Medical Officer of Health of Newcastle-upon-Tyne.
}

Has a butcher the right to sell the flesh of a tuberculous animal for human food? The occurrence in London within the iast week or two of a prominent case-in which a certain firm not only claimed, but were conceded, this right, after tho detention of a carcass of beef by the officers of the sanitary authority-marks the acute stage at which the conflict between purvoyors of meat and the official protectors of its consumers has arrived on this always important question. The statement of the case as published by the firm (the medical officer of health whose action is described has not yet, I believe, issued his reply) raises many points strikingly illustrative of the question at large, and therefore claiming the serious attention of all medical officers of health and meat inspectors, as it is probable that the example above indicated will be followed by other firms and butchers' associations throughout the country.

With regard to the position of the meat trade in the matter of tuberculosis, I mish to say at the outset that my sympathies are to a considerable extent with the butcher, from the fact that the cattle he buys as sound may, on slaughter, turn out to be diseased, and, through no fault of his, have to be destroyed, to his loss. The customs of the trade also, supported occasionally,-perhaps, by official indecision or laxity, may have tended to encourage the idea that a little tubercle is of no great consequence. Not unnaturally, therefore, the owner of a carcass of meat affected with what he may have been told is a mild or localized ailment, objects to its entire destruction.

But, whilst fully appreciating the difficulties of the butcher's position as relates to tuberculous ment, it must not be forgotten that he can always safeguard himself by purchasing subject to the meat boing "passed" after slaughter. By doing so he would compel stock-breeder's to take steps for stamping out the disease from their herds. This matter has not yet received the attention its importance merits. It is also open to him to protect himself, as many butchers do, by insurance.

Let us now turn to the proper subject of this paper. Purveyors

* Iiead before the Northern Branch of the Incorporated Society of Medical Ofticers of Health, May, 1900. 
of meat appear to think, and, indeed, freely affirm, that the medical officer of health or inspector who causes the seizure of an entire carcass of beef on account of tubercle in only one part or organ is acting wrongly. This idea is based on failure, on the part of the trade, to distinguish betreen the disease and its manifestations. In the case in question, as in general, the butchers and their well-known veterinary advisors confound tubercle with tuberculosis. The danger from the flesh of a tuberculous ox lies not only in the fixed tubercles, but in the free bacilli which gare rise to them, and of whose invisible presence they are the tangible proof. These organisms, circulating in the fluids of the body-and not the tubercles only-constitute the discase, which, like other zymotic diseases, has its period of incubation before the occurrence of the characteristic lesions rendering it recognisable to the nalied eye. The universality of these organisms or their products in the diseased animal is proved-by the tuberculin test; or by the feeding of other animals with the juice from the apparently unafiected flesh, or by inoculating them with the juice expressed from it.*

The appearance of tubercle in the tissues and organs affords no evidence of the departure of the bacilli from the fluids of the body, any more than the eruption of small-pox or typhus fever on the skin is evidence of the disappearance of infection from the interior. Tuberculosis, the disease, is always general; tuberele, the symptom, on the other hand, is always localized. To aftirm, as do the veterinary experts in the case in question, that tuberculosis is "localized" when lungs, bronchinl glands, liver, and mesenteric lymphatic glands are what one of these gentlemen terms "slightly. affected" is absurd.

When, as in the above instance, several parts are charged with tubercle, the absence of that pathological product from the rest of the carcass cannot be positively affirmed without minute dissection of the flesh; neither can any statement as to the absence of tuberculosis from the muscles, etc., be justifiable without an oxhaustive bacterial examination or inoculation tests with the fluids. Yet, apparently without any such inquiry, the veterinary professors in this case, whilst admitting the presence of tuberculosis in some of the viscera, did not lesitate to assert that the disease was "absosolutely localized" (or, in other words, confined to these organs), and that the rest of the carcass was " in prime condition."

Visible tubercles are never so universally distributed throughout the body that no particle of it is free from them; hence it goes

* Experiments of Dr. Sidney Martin (Royal Commission on Tuberculosis, 1895 ) and several other authorities. 
without saying they are always localized to the parts where they occur. But if we are to be guided in practice by the doctrine of localization, we shall never condemn more than these parts, no matter how numerous the tubercles; and in course of time may be told we are going too far in doing this, seeing that thorough cooking of the flesh kills the bacilli!

Whatever the views of veterinarians or butchers, we may be sure the public will not regard the meat of a tuberculous animal as healthy, any more than they will regard any part of a consumptive person as free from disease; nor will the consumer willingly pay for such as sound meat. The sale of it without declaration as to its real nature is $\Omega$ fraud.

'The responsibility of medical officers of health and meat inspectors is greatly increased by the effect of the heavy consequential expense in which they may by their action involve their sanitary authorities. The Report of the Royal Commission on Tuberculosis is by no means a universal guide as to the conditions under which a carcass should or should not be condemned. The rules there laid down, although calculated to stimulate a lax officer, are of but little help to others, as they are neither pathologically satisfactory, legally authoritative, or even generally applicable to the great majority of everyday cases.

The medical officer of health may, in passing, be reminded that it is his duty to satisfy his authority, and not necessarily the meat trade, by his action. In this respect he holds a different position to the veterinary surgeon, whose duty is to satisfy his client. The medical oflicer of health will often do well to reserve for his authority all explanation or justification of his procedure. In dealing with tuberculous meat, as he may at any time; and on very short notice, be called on to do-whether he rejects the nauseous doctrine of localization or otherwise, he should, as far as possible, make up his mind beforehand as to where he will draw the line between "pass". and "seizure," and, having done so, proceed to act with decision and firmness. He should be fully prepared for the possible consequencess of his action, which, whatever it may be, he must bear in mind concerns the public, the sanitary authority, and the trade. IIo should hesitate before being led by the customs of the butchers, which, in so far as they are dictated by commercial instincts, tend to make his duty harder to do.

In practice the medical officer of health is brought much into communication with the members of the veterinary profession, with whom it is to the general interest that he should work on cordial terms. Such a relationship is as necessary in its own way as that 
which, in matters afiecting human diseases, exists between his medical brethren and himself. The opinion of the veterinary surgeon as regards the diseases of animals-which is, of course, paramount-is often of the greatest value to the medical officer of health. But there the function of the veterinary surgeon in public health work ends. It is for the medical officer of health to say what is and what is not fit for human food. That has been my practice during a long official life, in which my association with the members of the sister profession in the North of England has been invariably harmonious and helpful. This satisfactory experience is, I think, largely due to the fact that both they and I have kept our proper positions in relation to each other.

In conclusion, the following practical suggestions are offered, in the hope of their being acceptable to younger medical officers of healtl.

When called on to deal with butcher's meat, make your examination quite complete before forming your opinion. Avail yourself of all the information you can get from veterinary surgeons, butchers, or inspectors. Weigh carefully the consequences, to both sides, of your decision. Make your judgment carefully and deliberately, express it clearly and decidedly, and adhere to it firmly. When in doubt as to seizure or otherwise, consult, if possible, a medical officer of health of greater experience than yourself, bearing in mind that your consultant may also have to be your witness. In view of opposition in Court, it is well to know several witnesses of weight, on whose opinion and testimony in support of your action you can rely.

Condemnation of a carcass does not necessarily imply seizure and carrying of it before a magistrate. Seeing the unsettled state of the question of the Eale of tuberculous meat, destruction of it by the owner's consent will often, under existing circumstances, be sufficient. In such cases care should always be taken to obtain that consent in writing.

Euptyisg Cesspoors.- We have received the following: "The Harpenden authorities have recently acquired an improved vacuum cesspool-exhauster capable of emptying cesspools in a very economical and cleanly manner. The sewage being drawn quickly up into a large air-tight tank without exposure, no offensive smells - so abominably characteristic of the old method-are caused. In consequence of this the plant can be operated during the daytime without rendering its presence in any way objectionable to persons in the locality. The apparatus is of Merryweathers' make." The principle appears to be that of Lienuhr. 